\title{
Artificial Reefs and People: How We Create Them and How They Affect Us ${ }^{1}$
}

\author{
Lisa Chong, Keith Mille, Holly Abeels, Victor Blanco, and Edward V. Camp²
}

\section{Abstract}

Artificial reefs serve coastal communities and fisheries around the world. They have a range of ecological and economic effects. This publication gives an overview of the agencies and people involved with artificial reefs. It also describes how these groups of people think about reefs and influence their deployment. Finally, this document also describes the process for how most artificial reefs are implemented in Florida. While a lot of science has described the biological effects of artificial reefs, more science is needed to help make good decisions about future artificial reefs that will affect both fish and people.

\section{Background on Artificial Reefs}

Artificial reefs are "objects of natural or human origin deployed ... on the seafloor to influence physical, biological, or socioeconomic processes related to living marine organisms" (Seaman and Jensen 2000). These physical processes can include protecting habitats. Biological roles include enhancing or restoring fish populations and increasing biodiversity. Socioeconomic benefits include improved recreational fishing, diving, and tourism opportunities. Artificial reefs may help prevent degrading of natural reefs. Scientists have extensively researched the biological and ecological impacts of artificial reefs on fish populations.
However, managers and users should be aware of a number of other factors when making decisions about the placement and use of artificial reefs. These factors include users' perceptions of artificial reefs, unintended or unexpected consequences associated with artificial reefs, and processes associated with reef design and deployment. This document provides a summary of the processes involved in permitting and implementing artificial reefs. It will help county reef coordinators and local governments understand what factors to consider when discussing artificial reef implementation. It will also help fishers and divers have realistic expectations of artificial reefs.

\section{Types of People Involved with Artificial Reefs}

Different groups of people interact with artificial reefs, including:

- Scientists who research the biology, ecology, and even economics of artificial reefs

- Resource managers like the Florida Fish and Wildlife Commission (FWC) who apply, develop, and implement rules for deploying artificial reefs

- Regulators like the United States Army Corps of Engineers (ACE) and the Florida Department of

1. This document is FA231, one of a series of the Program in Fisheries and Aquatic Sciences, School of Forest Resources and Conservation, UF/IFAS Extension. Original publication date February 2021. Visit the EDIS website at https://edis.ifas.ufl.edu for the currently supported version of this publication.

2. Lisa Chong, PhD student, School of Forest Resources and Conservation; Keith Mille, Division of Marine Fisheries Management, Florida Fish and Wildlife Conservation Commission; Holly Abeels, UF/IFAS Extension Brevard County Florida Sea Grant agent; Victor Blanco, UF/IFAS Extension Taylor County Florida Sea Grant agent; and Edward V. Camp, assistant professor, School of Forest Resources and Conservation; UF/IFAS Extension, Gainesville, FL 32611.

The Institute of Food and Agricultural Sciences (IFAS) is an Equal Opportunity Institution authorized to provide research, educational information and other services

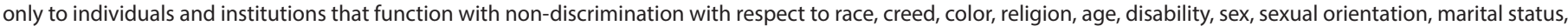

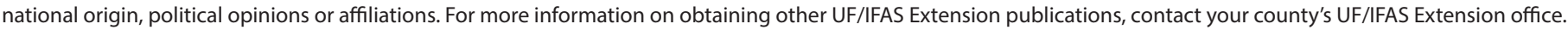
U.S. Department of Agriculture, UF/IFAS Extension Service, University of Florida, IFAS, Florida A \& M University Cooperative Extension Program, and Boards of County Commissioners Cooperating. Nick T. Place, dean for UF/IFAS Extension. 
Environmental Protection (DEP) that provide permits for artificial reef deployment

- Manufacturers who design and build reefs as part of their business

- Local government workers, including those from different programs (programs designed to promote or implement artificial reefs, for instance, or recreation programs), as well as appointed or elected officials such as county commissioners

- Local business people such as fishing and dive store owners or those in tourism/service industries

- End users, the people who use artificial reefs for fishing and diving

These groups of people have different roles in developing artificial reefs. Scientists often use reefs to better understand marine systems, especially ecological and economic processes. Their analyses can provide guidance to resource managers, manufacturers, local government, local businesses, and end users (Becker et al. 2018). Resource managers make sure that artificial reef programs are compliant with permit conditions. But they also balance this with end-user desire for reefs with any ecological concerns. Regulators consult with resource managers and local government to make sure that they plan for reef design, location, types of materials, maintenance, monitoring, and managing reefs to meet applicable federal laws and regulations. Manufacturers of reefs help identify innovative, practical, and cost-effective designs that also consider the life history and ecology of reef species. They need to create designs that also adhere to the requirements made by ACE.

The local government can affect local or state artificial reef policies and receive funds for artificial reef projects. Local businesses often benefit from the increased customers that artificial reefs can bring. End users usually include fishers and divers who get satisfaction from using the artificial reefs for recreation. But end users can also include people who depend on reefs, like fishing or diving guides or commercial fishers (Figure 1). End users could also be involved with non-governmental organizations, including volunteer or citizen-science-based programs to collect and share data about artificial reefs. This helps document artificial reef performance. All these people have an interest in artificial reefs that drives reef planning, construction, and monitoring (Lindberg and Seaman 2011).

Table 1 describes which stakeholders are part of each group and their direct and indirect effects on artificial reef systems. Direct impacts are the immediate result of a group's actions, whereas indirect impacts occur as a result of the direct impacts. It is important to remember that these are only general categories and that often people play multiple roles.

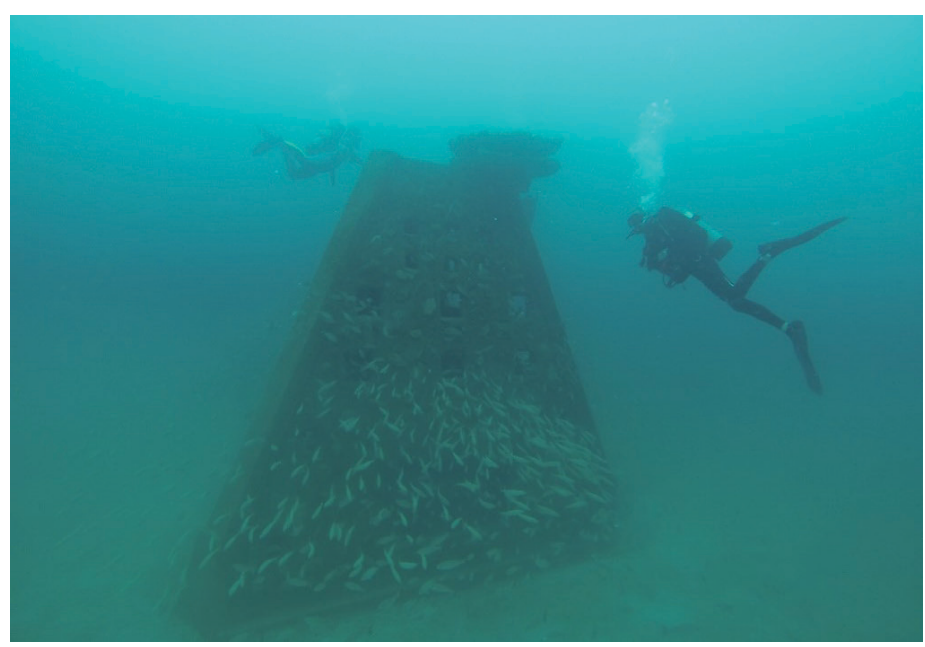

Figure 1. Artificial reefs are popular with fish and people.

Credits: Keith Mille

\section{Perceptions of Artificial Reefs}

Artificial reefs' benefits are viewed differently among and even within different stakeholder groups. Scientists, for example, have long debated whether artificial reefs enhance ecosystem productivity, or, rather, act as "ecological traps" that lure fish to areas where they are more easily caught. This is often referred to as the "attraction-production" debate and is described in Lindberg (1997). Most scientists now think both production and attraction happen. Which process is more important probably depends on fish species and surrounding habitat (Bortone 2011). Scientists also recognize that artificial reefs attract people in addition to fish. This can lead to more fishing trips taken, and ultimately can result in greater fishing mortality (Karnauskas et al. 2017). Overall, most scientists are "neutral" on reefs. Most resource managers and regulators are also neutral regarding artificial reefs. At the same time, resource managers also want to understand how artificial reefs can increase local economies without damaging ecosystems (such as by increasing fishing mortality). More information about this is described in Bortone (2011).

Reef manufacturers typically support expanding the implementation of artificial reefs because that may increase their profitability. Some may see the artificial reef construction industry as promoting consumer satisfaction and making good use of existing materials like concrete and rock materials from building construction sites. Local government (such as county managers and elected officials) likely perceives artificial reefs positively because their deployment could bring in tourism and visitation, which would contribute to an increase in economic activity and 
jobs. Local businesses could also benefit from artificial reefs because they can attract tourists to the deployment areas. However, if reefs attract tourists to one area, they may decrease tourism to other areas (depending on whether artificial reefs "attract" or "produce" tourism trips), especially if deployments change the spatial patterns of use (Sutton and Bushnell 2007). Economic effects of artificial reefs are described in some of the publications found here (https://edis.ifas.ufl.edu/topic_artificial_reefs).

End users have generally positive attitudes towards artificial reefs. They gain more fishing and diving opportunities from artificial reef deployments, which add a variety of fishing and/or diving experiences by providing different types of structures and attracting various kinds of life (Sutton and Bushnell 2007). The volunteer and/or citizen-science-based programs keep end users motivated, which helps secure future funding for artificial reef programs.

\section{Possible Unintended and Unidentified Impacts and Consequences of Artificial Reefs}

There is a need for additional research that evaluates how well artificial reefs perform as habitat for fish and other marine organisms. One area that needs more research is artificial reef material and design. We need to know how different materials are "viewed" differently by fish and result in different ecological and economic outcomes. While more unique and iconic projects (such as large shipwrecks, artistic sculptures or underwater memorials) may attract more attention, the majority of artificial reefs implemented in Florida are more similar to the local natural habitat and are made of smaller, lower-profile materials like concrete and rocks (Figure 2).

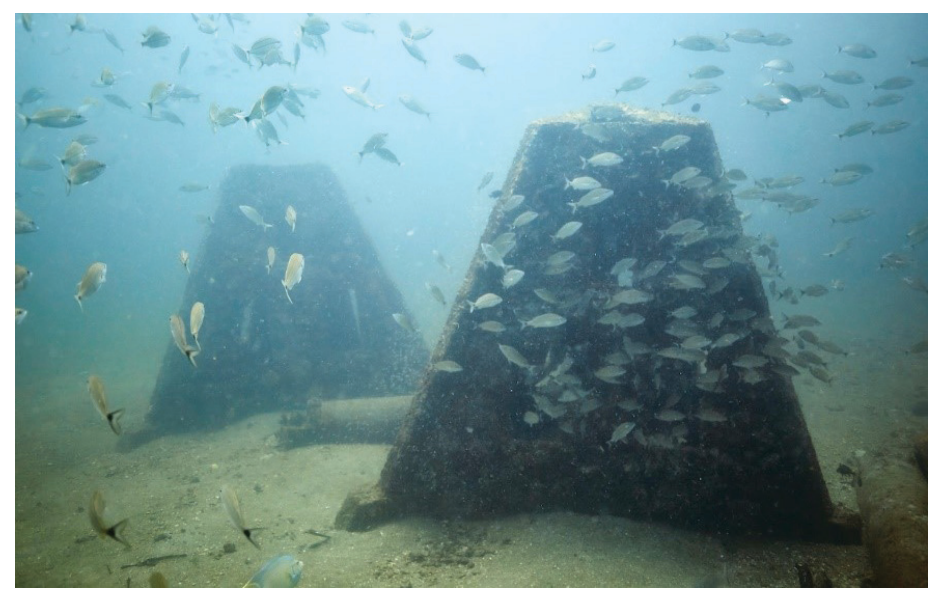

Figure 2. While "high-profile" reefs like steel vessels, planes, army tanks, etc. do exist, the majority of artificial reefs implemented in Florida are lower-profile items.

Credits: Keith Mille
A related issue is how artificial reefs ultimately affect fisheries. Increasingly, research suggests that artificial reefs increase catch rates in the short-term (Karnauskas et al. 2017). But these greater catch rates may actually lead to a greater harvest of some species. Increased harvest could eventually lead to overfishing and/or stricter regulations and shorter harvest seasons that might have net negative effects on communities and businesses (Sutton and Bushnell 2007; Karnauskas et al. 2017). Of course, these phenomena will vary by species and location, and not all artificial reef deployments should be expected to lead to increased harvest. Some reefs might be designed to attract species that are not close to being over-harvested. But it is clear that stakeholders involved with artificial reefs-from scientists to managers to end users-should consider the different ways that these semi-permanent habitat alterations affect fish populations.

Florida's artificial reefs currently do not seem to be causing much conflict among end users, but future challenges may exist. Artificial reefs could increase crowding and congestion if the deployments are not well placed or if the same locations prove very popular with end users from different sectors. There is a "gear conflict" possibility if the artificial reefs result in loss of recreational or commercial fishing gear. This may require more "zoning" of marine areas. A related issue is that there is growing evidence that artificial reefs may cause accidental mortality of sea turtles that become trapped inside the reefs or entangled in fishing gear attached to the reef (Barnette 2017). For all these potential conflicts, proper artificial reef planning must consider the full range of different users and the myriad ways in which artificial reefs will affect people.

\section{Implementing Artificial Reefs in Florida}

Florida has one of the most active and diverse artificial reef programs in the United States. As of November 2019, there are over 3,600 permitted artificial reef sites representing 34 of 35 coastal counties in Florida. Florida is the only southeastern Atlantic coastal state that does not have a direct state-managed artificial reef program (SAFMC 2018). Artificial reefs are deployed under general guidelines established by FWC specified within the State of Florida Artificial Reef Strategic Plan, and are approved by regulatory agencies ACE and DEP (FWC 2003). These regulatory agencies are mostly associated with siting. Siting involves making sure the reefs are not placed on sensitive habitat or in areas where they would pose a navigational hazard. There is relatively little input on artificial reef design 
and placement from the fisheries-management perspective. FWC, though, does assist financially using funds generated through the state saltwater fishing license revenue and federal sport fish restoration funding. The implementation process often starts with pressure from end users at the local level and typically involves a number of different governance and stakeholder groups. Examples of groups that many end users in Florida are involved in are the Palm Beach Reef Research Team, Mexico Beach Artificial Reef Association, Organization for Artificial Reefs, and Taylor County Reef Research Team.

An example process of implementing artificial reef development in Florida is depicted in Figure 3. Initially, end users are interested in implementing artificial reefs off a certain county. These end users then contact their local government and/or the county artificial reef manager. If interested, the county government will contact ACE and DEP to identify potential siting areas and to apply for the relevant permits. ACE will grant final approval for the implementation at the requested sites if they are suitable for artificial reefs. FWC is typically the contact for financial and technical assistance. FWC also helps review permit applications and aids in outreach efforts to include stakeholders in artificial reef planning activities. County governments and/or FWC will set up contracts for obtaining the materials and moving them into the water. Once the artificial reefs are constructed and deployed, they are advertised by making the GPS coordinates publicly available so that end users can locate them. These are then used by tourist development councils and other groups to promote marine tourism.

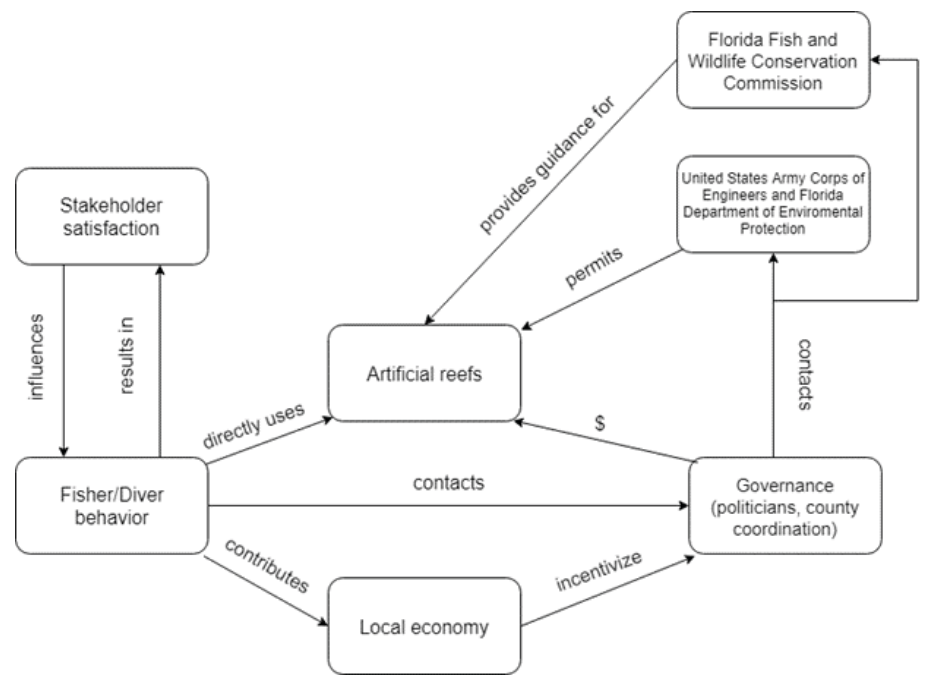

Figure 3. Process of artificial reef implementation in Florida. This figure depicts the interaction among stakeholders and primary users and shows how their influences affect the implementation of artificial reefs.
Federal fisheries management agencies (e.g., NOAA NMFS) are typically not directly involved in strategic planning of artificial reefs for Florida's marine fisheries. But there are special cases in which artificial reefs are implemented directly from federal agencies. For example, in areas impacted by oil spills, hazardous waste, or ship groundings, federal agencies like NOAA can use mitigation settlement funds or Natural Resources Damage Assessment (NRDA) funds to plan the implementation of artificial reefs. NRDA is the legal process where federal agencies assess the impacts, plan potential restoration projects, and implement restoration activities. For example, from 2016 to 2019, after the Deepwater Horizon Oil Spill federal NRDA funding helped local county and state agencies to deploy 470 patch reefs off Escambia to Bay Counties.

There is some concern artificial reefs could conflict with other uses for the same marine space. Special management zones (SMZs) are designated to reduce conflicts. These might include crowding between fishers and divers, or commercial fishing and aquaculture gear getting tangled on the reefs. SMZs also need to achieve conservation benefits without the negative consequences of fishing pressure while maintaining other recreational uses (Murray and Betz 1994). The South Atlantic Fishery Management Council within the Snapper/Grouper Management Plan has established SMZs in the South Atlantic off South Carolina, Georgia, and Florida to provide gear and harvest regulations at defined locations, including some artificial reef sites (SAFMC 2018). As of March 2018, there are about 50 artificial reefs with SMZ designation off the South Atlantic States. SMZs are recognized in the Magnuson-Stevens Fishery Conservation and Management Act and in the National Artificial Reef Plan as habitat areas of particular concern within essential fish habitat (NMFS 2002), and it is likely that additional artificial reef sites will be designated as SMZs as the construction and implementation of these habitats continues to expand in Florida.

\section{Conclusion}

Artificial reefs affect a variety of people, here described as stakeholder groups. Many of the stakeholder groups appear to have generally positive opinions of artificial reefs based on their personal fishing and diving experiences at specific artificial reef sites. However, these reefs could have negative long-term effects on those same stakeholders in terms of stock-assessment-level marine fisheries management. This can occur if the implemented reefs decrease the fish populations or create additional conflict among stakeholders interested in using the same artificial reefs or associated fisheries. Although artificial reefs could increase visitation 
and catchability at specific sites, there is a component of production at each new reef site to some degree, as well as attraction of users that could draw users away from habitats that would have been visited otherwise. While extensive and ongoing research has been conducted about artificial reefs and how artificial reefs affect fish and ecosystems, much less research has explored how these reefs affect human behaviour. Both future research and management carefully consider the way that artificial reefs may affect different groups of people.

\section{References}

Barnette, M. C. 2017. "Potential Impacts of Artificial Reef Development on Sea Turtle Conservation in Florida." NOAA Technical Memorandum NMFS-SER-5, 36 pp. https://doi.org/10.7289/V5/TM-NMFS-SER-5.

Becker, A., M. D. Taylor, H. Folpp, and M. B. Lowry. 2018. "Managing the Development of Artificial Reef Systems: The Need for Quantitative Goals." Fish and Fisheries 19:740-752.

Bortone, S. 2011. "A Pathway to Resolving an Old Dilemma: Lack of Artificial Reefs in Fisheries Management." In Artificial Reefs in Fisheries Management, edited by Stephen A. Bortone, Frederico Pereira Brandini, Gianna Fabi, and Shinya Otake, 311-321. CRC Press.

Florida Fish and Wildlife Conservation Commission. 2003. State of Florida Artificial Reef Strategic Plan. Division of Marine Fisheries Management, Tallahassee, FL.

Karnauskas M., J. F. Walter, M. D. Campbell, A. G. Pollack, J. Marcus Drymon, and S. Powers. 2017. "Red Snapper Distribution on Natural Habitats and Artificial Structures in the Northern Gulf of Mexico." Marine and Coastal Fisheries 9:50-67. https://doi.org/10.1080/19425120.2016.1255684

Lindberg, W. J. 1997. "Can Science Resolve the AttractionProduction Issue?” Fisheries 22:10-13.

Lindberg, W. J., and W. Seaman. 2011. "Guidelines and Management Practices for Artificial Reef Siting, Use, Construction, and Anchoring in Southeast Florida Southeast Florida Coral Reef Initiative." Florida Department of Environmental Protection. Miami, FL. xi and 150 pages.

Murray, J. D., and C. J. Betz. 1994. "User Views of Artificial Reef Management in the Southeastern U.S.” Bulletin of Marine Science.
NMFS. 2002. National Artificial Reef Plan revision. Federal Register 67:8233.

NOAA Marine Debris Program. 2015. "Report on the Impacts of 'Ghost Fishing' via Derelict Fishing Gear." Silver Spring, MD. 25 pp.

SAFMC. 2018. "Fishery Ecosystem Plan II Artificial Reef Habitat March 2018." South Atlantic Fishery Management Council, 4055 Faber Place Drive, Suite 201; North Charleston, SC 29405.

Seaman, W., and A. C. Jensen. 2000. Purposes and practices of artificial reef evaluation. Artificial Reef Evaluation: With Application to Natural Marine Habitats. Boca Raton: CRC Press. https://doi.org/10.1201/9781420036633

Sutton, S. G., and S. L. Bushnell. 2007. "SocioEconomic Aspects of Artificial Reefs: Considerations for the Great Barrier Reef Marine Park." Ocean and Coastal Management 50:829-846. https://doi.org/10.1016/j. ocecoaman.2007.01.003 
Table 1. Groups that are involved with artificial reefs, who are they made of, and direct and indirect impacts they have on artificial reefs.

\begin{tabular}{|c|c|c|c|}
\hline Group & Comprised of & Direct Effects & Indirect Effects \\
\hline Scientific community & $\begin{array}{l}\text { - Researchers } \\
\text { - Fish biologists and ecologists } \\
\text { - Social scientists }\end{array}$ & $\begin{array}{l}\text {-Advise managers through } \\
\text { artificial reef assessments }\end{array}$ & $\begin{array}{l}\text { - Influence resource managers on } \\
\text { decisions } \\
\text { - Monitor reefs }\end{array}$ \\
\hline Resource managers & $\begin{array}{l}\text { - State fisheries managers (FWC) } \\
\text { - Federal fisheries managers (NMFS, } \\
\text { Fishery Management Councils) }\end{array}$ & $\begin{array}{l}\text { - Assess artificial reefs } \\
\text { - Disperse state and federal } \\
\text { funds for artificial reef } \\
\text { development }\end{array}$ & $\begin{array}{l}\text { - Provide rules for artificial reef end } \\
\text { users } \\
\text { - Manage area used } \\
\text { - Influence national, state and regional } \\
\text { artificial reef development }\end{array}$ \\
\hline Regulators & $\begin{array}{l}\text { - Army Corps of Engineers (ACE) } \\
\text { - Florida Department of } \\
\text { Environmental Protection (DEP) }\end{array}$ & $\begin{array}{l}\text { - Permit artificial reef } \\
\text { constructions }\end{array}$ & $\begin{array}{l}\text { Establish thresholds for allowable } \\
\text { materials and permit areas }\end{array}$ \\
\hline Manufacturers & - Reef planners and builders & $\begin{array}{l}\text { - Supply artificial reef materials } \\
\text { and designs }\end{array}$ & - Support people using artificial reefs \\
\hline Local government & $\begin{array}{l}\text { - County resource managers } \\
\text { - Elected officials }\end{array}$ & $\begin{array}{l}\text { - Influence policies and plans } \\
\text { about artificial reefs } \\
\text { - Hold permits } \\
\text { - Implement new artificial } \\
\text { reefs }\end{array}$ & $\begin{array}{l}\text { - Provide new fishing opportunities } \\
\text { - Apply for state/federal funding }\end{array}$ \\
\hline Local businesses & $\begin{array}{l}\text { - Boating industry } \\
\text { - Fishing retailers } \\
\text { - Diving and fishing charters } \\
\text { - Hotels } \\
\text { - Restaurants }\end{array}$ & $\begin{array}{l}\text { - Support people using } \\
\text { artificial reefs } \\
\text { - Create jobs and bring money } \\
\text { into the local economy }\end{array}$ & $\begin{array}{l}\text { - Influence end users } \\
\text { - Inform managers } \\
\text { - Provide economic benefits } \\
\text { - Justify artificial reef investments }\end{array}$ \\
\hline End users & $\begin{array}{l}\text { - Fishers } \\
\text { - Recreational } \\
\text { - Commercial } \\
\text { - Divers }\end{array}$ & $\begin{array}{l}\text { - Determine user behaviors } \\
\text { - How much, where, and } \\
\text { what species to fish or dive } \\
\text { for } \\
\text { - Inform managers }\end{array}$ & $\begin{array}{l}\text { - Cause fish population change } \\
\text { - Recruitment } \\
\text { - Natural and fishing mortality } \\
\text { - Fish movement } \\
\text { - Increase fishing/diving trips } \\
\text { - Increase fisher/diver satisfaction }\end{array}$ \\
\hline
\end{tabular}

